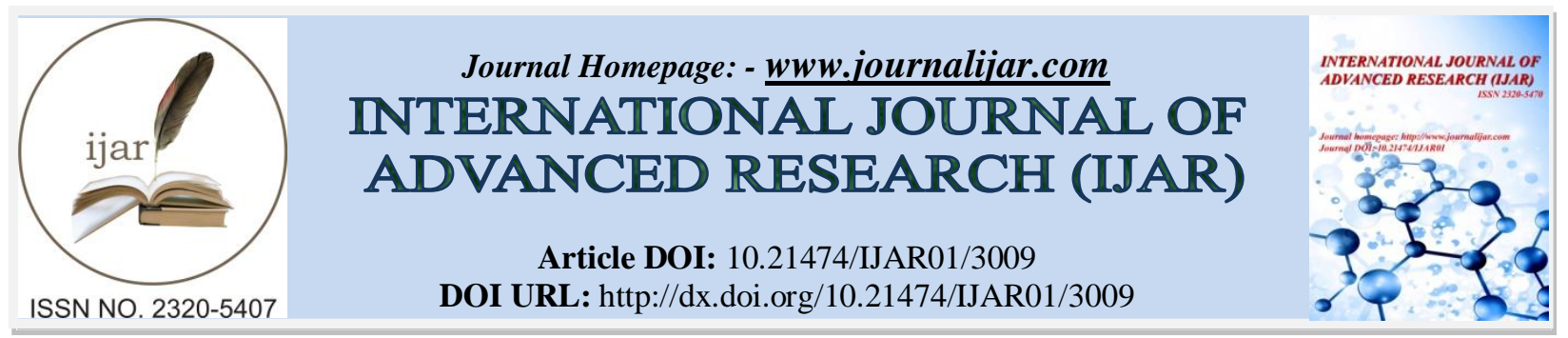

RESEARCH ARTICLE

\title{
GROWTH AND YIELD OF UPLAND RICE WITH THE ADDITION OF COMPOST FROM OIL PALM EMPTY FRUIT BUNCHES AND FUNGI MYCORRHIZAL.
}

Chairani Hanum.

Agroecotechnology Deparment, Faculty of Agriculture, University of Sumatera Utara. Jalan Prof.A. Sofyan. No3 Kampus USU Padang Bulan- Medan.

\section{Manuscript Info}

\section{Manuscript History}

Received: 28 November 2016

Final Accepted: 27 December 2016

Published: January 2017

Key words:-

growth, mycorrhizal fungi,OPEFB

compost, upland rice, yield.

\section{Abstract}

The study was conducted in Cengkeh Turi Binjai with a soil $\mathrm{pH}$ of 4.2. The source of mycorrhizal inoculation using mycofer from The Forest of Inter-University Center of Bogor Agricultural Institute, with mycorrhizal contents (Gigaspora margarita, Glomus manihotis, Glomus etunicatum, and Acaulospora tuberculata). Planting was conducted in January-May 2014. The upland rice variety used as the indicator plant was Situ Bagendit. This study used a factorial randomized block design (RBD) with two factors. The first factor is a mycorrhizal inoculation consisting of two levels, i.e. without giving mycofer and by giving $5 \mathrm{~g}$ of mycofer per planting hole. The second factor was giving oil palm empty fruit bunches (OPEFB) composts in 3 levels: $0,3,375 \mathrm{~g}, 6,750 \mathrm{~g} / \mathrm{plot}$. The result of the research showed that (i) the dose of OPEFB composting of 3,375 g per planting hole can increase the number of productive tillers and panicles; and (ii) the addition of OPEFB compost (3,375 g/planting hole) and mycorrhizal inoculation ( $5 \mathrm{~g}$ mycofer/planting hole) can increase the number of filled grain of upland rice.

Copy Right, IJAR, 2016,. All rights reserved.

\section{Introduction:-}

The utilization of dry land is one of the resources with great potential both for food self-sufficiency stabilization and for future agricultural development. The need for rice has been met by rice paddy fields requiring land characteristics with relatively high fertility rates in their production. The characteristics of cultivation of such rice paddy fields, thus limit the opportunities for increased rice production through the expansion of paddy fields. This is due to the narrowness of reserve lands suitable for rice fields and the increasingly tight competition of water usage by industry, mining, and households (Abdurachman et al., 2008). National rice production has been relying on paddy fields; therefore, the national rice production has not been able to meet the needs for food (rice) sustainably.

Rice production in North Sumatra during the 2003-2013 period increased at an average of $0.92 \%$ per year. The average growth in rice paddy field production was $1.12 \%$ per year, while upland rice decreased at an average of 2.78\% per year (Biro Pusat Statistik, 2015). According to the Central Bureau of Statistics of North Sumatra Province (BPS), the upland rice harvested areas reached 50,792 hectares with total production of 163,143 tons and average productivity of 3.2 tons/hectare. The productivity of upland rice is still relatively low compared to rice paddy field productivity, which has reached 5.1tons/hectare. The low productivity of upland rice is caused partly by very varied climatic and soil conditions, drought stress, and lack of a dryland rice cultivation technology. Some of 
the obstacles leading to the low productivity of upland rice are thought to be caused by the land generally planted belongs to Ultisol soil with various problems, such as low of :soil fertility, organic matter content, and water holding capacity.

Developing upland rice cultivation on dry land is a strategic alternative in order to meet national food needs of its relatively large potential. Nevertheless, upland rice cultivation often encountered drought stress due to its full dependence on rainfall. Drought stress will affect crop growth, development and yield. Drought is one of the main constraints on crop productivity world wide and is expected to increase with climate change (IPCC, 2007 and the European Environmental Agency, 2011).

Such condition certainly requires efforts to improve upland rice production one of which is through improved cultivation system by adding compost from oil palm empty fruit bunches (OPEFB) and mycorrhizal fungi.

Compost from waste of oil palm mills in the form of empty fruit bunches (EFB) is one of potential raw material sources for composting because of its availability in large volumes. As an illustration, each ton of FFB (Fresh Fruit Bunches) processed would generate $20 \%$ or $200 \mathrm{~kg}$ of empty fruit bunches (Wijaya et al., 2001). OPEFB, which is $23 \%$ of the fresh fruit bunches, contains lingo cellulosic materials as much as 55-60\% of dry weight (Rahmalia et al., 2006). OPEFB has several advantages such as enriching the nutrients in the soil, and improving physical, chemical and biological characteristics of the soil. In their research, Hanum Ch, et al. (2006) found that OPEFB compost contains such nutrients as $\mathrm{N}, \mathrm{P}, \mathrm{K}$ and $\mathrm{Mg}$.

Loss of soil organic matter has caused agricultural losses of nearly 60 percent in sub-tropical areas and 70 percent in tropical areas. The loss of organic matter in the soil will cause loss of the energy source for soil microbes.

The allocation of soil organic carbon needed to associate with mycorrhizal fungi has been estimated to be around 5$20 \%$ of the total soil carbon (Hobbie and Hobbie, 2006).

Some of the research results revealed that there are nearly $80 \%$ of symbiotic associations between mycorrhizal fungi and vascular plants widespread in nature, and some ecophysiological studies indicate that symbiotic of mycorrhizal fungi is a key component in helping plants to overcome and improve resistance to abiotic stress (Auge, 2001; RuizLozano, 2003; Barea et al., 2011; Ruiz-Sanchez et al., 2010). Association of mycorrhiza in plants is one of the ways to overcome the growth inhibition due to drought stress. Mycorrhiza is symbiotic associations established between soil fungi and most vascular plants. The working principle of mycorrhiza is infecting root system of the host plant, producing intensively interwoven hyphae so that the plant containing such mycorrhiza will be able to increase its capacity in the absorption of nutrients and water.

Inoculation of plant roots with mycorrhizal fungi has been thought to be effective in increasing crop production in drought conditions. Root colonization by mycorrhizal fungi has been proven to increase crop productivity in drought stress (Al-Karaki and Clark, 1998). Increased productivity of plants inoculated by mycorrhiza is caused by nutrient absorption enhancements such as phosphorus, zinc and copper. In addition, other factors associated with mycorrhizal colonization can influence plant resistance to drought, including changes in leaf elasticity, improved leaf water and turgor potential, maintenance of stomatal opening and transpiration (Auge et al., 1987), increased root length and depth, and external hyphae development (Davies et al.,1992).

Mycorrhizal fungi can form a strong plant root structure, quick transplant establishment, healthy roots and quick closing of the plant canopy's green leaves. The root of seed plants that has been inoculated with vesicular arbuscular mycorrhizal is able to survive in marginal environmental conditions. Mycorrhizae can help the plant and protect the plant roots from extreme environmental disturbance so that it has the ability to survive.

The objective of these research was to study growth response and yield of upland rice by providing OPEFB compost and mycorrhizal inoculation.

\section{Materials and Methods:-}

The study was conducted in Cengkeh Turi Binjai with soil pH of 4.9. The planting period was from January to May 2014, with the average rainfall within the five months was less than $100 \mathrm{~mm}$ (according to The Regional Agency for Meteorology, Climatological and Geophysics (RAMCG), Medan). The source of mycorrhizal inoculation used 
mycofer from the Forest of Inter-University Center of Bogor Agricultural Institute with mycorrhizal contents (Gigaspora margarita, Glomus manihotis, Glomus etunicatum, and Acaulospora tuberculata). This study used a factorial randomized block design (RBD) with two factors. The first factor was mycorrhizal inoculation (M) consisting of two levels, without giving mycofer and by giving $5 \mathrm{~g}$ of mycofer per planting hole. The second factor was giving OPEFB composts in 3 levels: $0,3.375,6.750 \mathrm{~g} /$ planting hole. The examination on the percentage of endomycorrhizal infection was used a staining method.

The percentage of root infected by arbuscular mycorrhizal fungi (AMF)was calculated using the formula:

$$
\% \text { of infected roots }=\frac{\text { The number of infected roots }}{\text { The total number of observed roots }} \times 100 \%
$$

\section{Result and Discussion:-}

Before been applied to the planting media, the analysis of chemical fertility of OPEFB compost as presented in Table 1 and chemical fertility of basic soil as presented in Table 2 had been carried out.

Based on the OPEFB fertility analysis, it was found that the nutrient content of organic materials generally have low criteria. The OPEFB compost was classified as alkaline, with moderate organic matter, content, different from the soil at the research location that had a low pH value (4.2) (SeeTable 2).

\section{Productive tiller per hill:-}

The results of statistical analysis indicated that the treatment of OPEFB composts, significantly affected the number of productive tillers, whereas the provision of mycorrhizal fungi and the interaction between the two treatments do not affect significantly.

The increased OPEFB composting will increase the number of rice tillers (Table 1). There is a variety of assumptions concerning the high number of productive tillers in rice composted by OPEFB, i.e. an increase in $\mathrm{pH}$ and organic matter provision can increase the ability of soil to absorb water. The OPEFB composting analysis results (Table 1) indicate high organic matter content in the OPEFB. The higher of biomass and high seed production in wheat given mycorrhizal fungi than those which is not given is caused by the ability of plants to extract water from the soil solution (Al-Karaki et al., 2004).

The addition of OPEFB compost with this alkaline $\mathrm{pH}$ (pH: 8.63) will affect the balance of cations and anions in the soil. (Mc Cauley et al., 2009).

Soil organic matter contributes to biological, chemical, and physical properties of soil. The addition of organic matter to the soil will affect the amount and the rate of organic matter decomposition and nutrient mineralization. Organic matter helps the availability of nutrients by increasing the cation exchange capacity of the soil, providing chelates, and increasing the solubility of certain nutrients in the soil solution. Furthermore, the humus fraction of organic matter can improve soil structure by increasing soil, water storage capacity, infiltration and aeration. Plants need to maintain high internal water pressure or "turgor" to increase the formation of cellulose fiber cells. When the water supply to the plant is relatively low, one of the main consequences is the inhibition of the growth of shoots and leaves (Eastin and Sullivan, 1984).

This is assumed to be the factor leading to increase in the number of upland rice tillers added byOPEFBcompost. The addition of organic matter can contribute to soil complex anda reductionof toxicity such as aluminum (Al) on acid soils (Tan and Binger, 1986), in addition to its ability to capture pollutants - herbicides or pesticides.

Mycorrhizal inoculation on upland rice has not been able to show an increase in the number of tillers. The results of observation on the mycorrhizal infection show that the highest average (70\%) was obtained in the planting medium inoculated with mycorrhizal and without composting (Table 4).

The results of this study indicate that the better soil conditions the ones with the organic matter addition will cause a decrease in the degree of mycorrhizal infection.It is assumed that such condition is caused by mycorrhizal potential to be maximized on marginal soil conditions. Allen (2001) also found a decrease in the percentage of the degree of infection in adequate water soil. 
Carrenho R et al.(2007) state that there is a close relationship between the percentage of the degree of infection and soil amendments (fertilization, organic matter and $\mathrm{pH}$ ) in which changes in the soil will affect the inoculation effectiveness produced. The decreased degree of mycorrhizal infection at the chickpea roots by the addition of $\mathrm{P}$ on acid soils is also found by Alloush et al. (2000). Nevertheless, several research as related to the effect of organic matter adding to the percentage of infection degree are very varied such as the research done by Joner and Jakobsen (1995) who found an increased growth in the number of hypha with the addition of organic matter.

I Putu and Sukawidana's (2011) research shows that the increased use of organic matter that reached mycorrhizal dose of $30 \mathrm{~g} / \mathrm{plant}$ and organic fertilizer of $30 \mathrm{~g} / \mathrm{plant}$ was able to increase the percentage of mycorrhizal infection on cashew. Increased provision of organic matter will stabilize $\mathrm{pH}$ : 7.6. Russell (1973) adds that a neutral soil pH, high organic matter content and low availability of nutrients (nitogen and phosphor) can encourage the growth of mycorrhizae.

Table 1:- The nutrient content of OPEFB compost.

\begin{tabular}{|l|l|l|l|l|}
\hline Parameter & & & Method & $\begin{array}{l}\text { Criteria } \\
\text { (The Department of Agriculture, } \\
1983)\end{array}$ \\
\hline Organicmaterials & 3.61 & $\%$ & Walkley and Black Titration & Moderate \\
\hline $\mathrm{BO}$ & 31.88 & $\%$ & Ashing & \\
\hline $\mathrm{N}$ & 0.28 & $\%$ & Kjeldahl & Low \\
\hline $\mathrm{P}$ & 0.09 & $\%$ & Spectrophotometry & Very low \\
\hline $\mathrm{K}$ & 0.80 & $\%$ & Flame photometry & Very low \\
\hline $\mathrm{Ca}$ & 0.21 & $\%$ & AAS & Very low \\
\hline $\mathrm{Mg}$ & 0.15 & $\%$ & AAS & Very low \\
\hline $\mathrm{B}$ & 86.87 & $\mathrm{ppm}$ & Spectrophotometry & \\
\hline $\mathrm{Fe}$ & 4200.00 & $\mathrm{ppm}$ & AAS & \\
\hline $\mathrm{Cu}$ & 10.95 & $\mathrm{ppm}$ & AAS & \\
\hline $\mathrm{pH}$ & 8.63 & & Electrometry & Mildlyalkaline \\
\hline
\end{tabular}

Table 2:- The nutrient content in the soil used

\begin{tabular}{|l|l|l|}
\hline Parameter & & Criteria (The Department of Agriculture, 1983) \\
\hline pH (H2O) & 4.2 & Acid \\
\hline Soil Moisture (\%) & 3.25 & \\
\hline C-organic (\%) & 1.96 & Very low \\
\hline N-total (\%) & 0.14 & Very low \\
\hline P-available (ppm) & 13.55 & Very low \\
\hline K-dd (me/100 g soil) & 0.06 & Very low \\
\hline P-Bray & 19.16 & Very low \\
\hline $\mathrm{Ca}$ & 0.08 & Very low \\
\hline $\mathrm{Mg}$ & 0.01 & Very low \\
\hline
\end{tabular}

Table 3:- The number of productive tillers of rice being treated with OPEFB compost and mycorrhizal inoculation

\begin{tabular}{|c|c|c|c|c|}
\hline \multirow{2}{*}{$\begin{array}{l}\text { Mycorrhizal } \\
\text { Inoculation (g } \\
\text { mycofer/hole) }\end{array}$} & \multicolumn{3}{|c|}{ OPEFB Compost (g/hole) } & \multirow[t]{2}{*}{ Average } \\
\hline & 0 & 3,375 & 6,750 & \\
\hline & \multicolumn{4}{|c|}{ 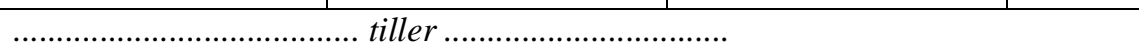 } \\
\hline 0 & 7.95 & 10.65 & 11.15 & 9.92 \\
\hline 5 & 7.05 & 11.85 & 12.25 & 10.83 \\
\hline Average & $7.50 \mathrm{~b}$ & $11.25 \mathrm{a}$ & $11.70 \mathrm{a}$ & 10.15 \\
\hline
\end{tabular}

Note : The number followed by different letters in the same column indicates significant difference at $5 \%$ level by Duncan's multiple range test (DMRT) 
Table 4:- The percentage of the mycorrhizal infection

\begin{tabular}{|c|c|}
\hline Treatment & \% degree of mycorrhizal infection \\
\hline M0K0 & $20 \%$ \\
\hline M0K1 & $40 \%$ \\
\hline M0K2 & $40 \%$ \\
\hline M1K0 & $70 \%$ \\
\hline M1K1 & $60 \%$ \\
\hline M1K2 & $60 \%$ \\
\hline
\end{tabular}

Table 5:- The number of panicles per plant with OPEFB compost treatment and mycorrhizal inoculation

\begin{tabular}{|c|c|c|c|c|}
\hline \multirow{2}{*}{$\begin{array}{l}\text { Mycorrhizal } \\
\text { Inoculation (g mycofer/hole) }\end{array}$} & \multicolumn{3}{|c|}{ OPEFB Compost (g/planting hole) } & \multirow[t]{2}{*}{ Average } \\
\hline & 0 & 3,375 & 6,750 & \\
\hline & \multicolumn{4}{|c|}{ 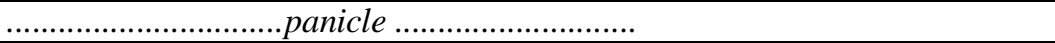 } \\
\hline 0 & 9.67 & 12.84 & 11.54 & 11.35 \\
\hline 5 & 9.31 & 14.20 & 11.80 & 11.77 \\
\hline Average & $9.49 \mathrm{c}$ & $13.52 \mathrm{a}$ & $11.67 \mathrm{~b}$ & 11.56 \\
\hline
\end{tabular}

Note:The number followed by different letters in the same column indicates significant difference at $5 \%$ level by Duncan's multiple range test (DMRT)

Table 6:- Number of filling grain crops with OPEFB compost treatment and mycorrhizal inoculation

\begin{tabular}{|c|c|c|c|c|}
\hline \multirow{2}{*}{$\begin{array}{l}\text { Mycorrhizal inoculation } \\
\text { (g mycofer/hole) }\end{array}$} & \multicolumn{3}{|c|}{ OPEFB compost (g/planting hole) } & \multirow[t]{2}{*}{ Average } \\
\hline & 0 & 3,375 & 6,750 & \\
\hline & \multicolumn{4}{|c|}{..1. } \\
\hline 0 & $1592.10 \mathrm{~d}$ & $2113.64 \mathrm{~b}$ & $1818.26 \mathrm{c}$ & 1841.33 \\
\hline 5 & $1534.53 \mathrm{~d}$ & $2338.20 \mathrm{a}$ & $1945.73 b c$ & 1939.49 \\
\hline Average & 1563.32 & 2225.92 & 1881.99 & 1890.41 \\
\hline
\end{tabular}

Note : The number followed by different letters in the same column indicates significant difference at $5 \%$ level by Duncan's multiple range test (DMRT)

Table 7:- The number of empty grain per plant with OPEFB compost treatment and mycorrhizal inoculation

\begin{tabular}{|c|c|c|c|c|}
\hline \multirow{2}{*}{$\begin{array}{l}\text { Mycorrhizalinoculation (g } \\
\text { mycofer/hole) }\end{array}$} & \multicolumn{3}{|c|}{ OPEFB compost (g/planting hole) } & \multirow[t]{2}{*}{ Average } \\
\hline & 0 & 3,375 & 6,750 & \\
\hline & \multicolumn{4}{|c|}{ 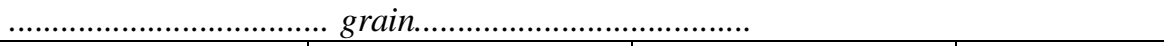 } \\
\hline 0 & $1265.12 \mathrm{~d}$ & $1443.05 \mathrm{c}$ & $1617.42 \mathrm{ab}$ & 1441.86 \\
\hline 5 & $1161.16 \mathrm{~d}$ & $1549.69 \mathrm{bc}$ & $1829.22 \mathrm{a}$ & 1513.36 \\
\hline Average & 1213.14 & 1496.37 & 1723.32 & 1477.61 \\
\hline
\end{tabular}

Noote : The number followed by different letters in the same column indicates significant difference at $5 \%$ level by Duncan's multiple range test (DMRT)

Table 8:- The production per plant with OPEFB compost treatment and mycorrhizal inoculation

\begin{tabular}{|c|c|c|c|c|}
\hline \multirow{2}{*}{$\begin{array}{c}\text { Mycorrhizal } \\
\text { inoculation (g } \\
\text { mycofer/hole) }\end{array}$} & \multicolumn{3}{|c|}{ OPEFB compost (g/hole) } & \multirow[t]{2}{*}{ Average } \\
\hline & 0 & 3,375 & 6,750 & \\
\hline & & ㄴ. & ... & \\
\hline 0 & 29.65 & 35.49 & 52.90 & 39.35 \\
\hline 5 & 23.16 & 44.19 & 44.90 & 37.42 \\
\hline Average & $26.41 \mathrm{~b}$ & $39.84 \mathrm{ab}$ & $48.90 \mathrm{a}$ & 38.38 \\
\hline
\end{tabular}

Note: $\quad$ The number followed by different letters in the same column indicates significant difference at $5 \%$ level by Duncan's multiple range test (DMRT) 
Table 9:- Production per plant with OPEFB compost treatment and mycorrhizal inoculation

\begin{tabular}{|c|c|c|c|c|}
\hline \multirow{2}{*}{$\begin{array}{l}\text { Mycorrhizalinoculation (g } \\
\text { Mycofer/hole) }\end{array}$} & \multicolumn{3}{|c|}{ OPEFB compost (g/ hole) } & \multirow[t]{2}{*}{ Average } \\
\hline & 0 & 3,375 & 6,750 & \\
\hline & \multicolumn{4}{|c|}{ 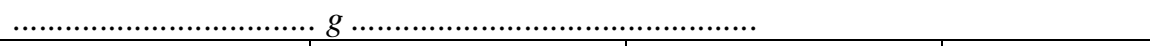 } \\
\hline 0 & 11.07 & 11.66 & 12.96 & 11.90 \\
\hline 5 & 12.36 & 13.09 & 15.69 & 13.71 \\
\hline Average & 11.71 & 12.37 & 14.32 & 12.81 \\
\hline
\end{tabular}

Note: The number followed by different letters in the same column indicates significant difference at $5 \%$ level by Duncan's multiple range test (DMRT)

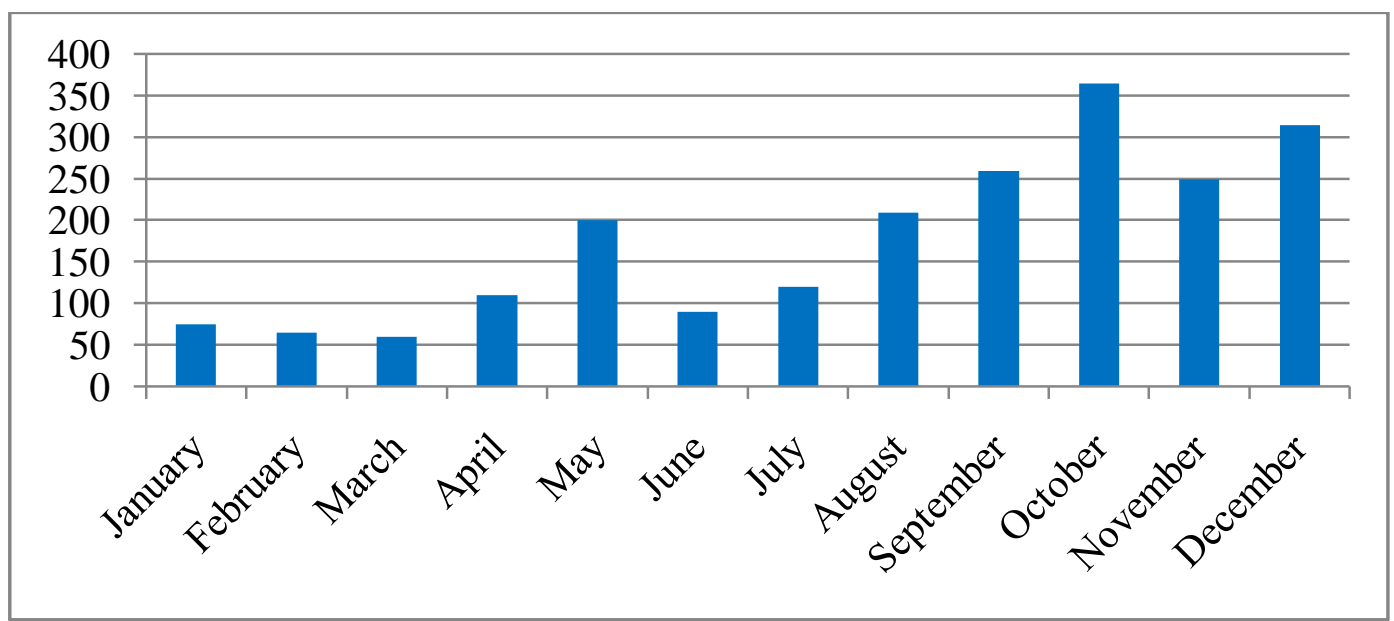

Figure 1:- The average rainfall during the planting period (January to December 2014)

\section{Number of panicles per plant:-}

The addition of OPEFB compost increases the number of panicles per plant, with the highest average dose of 3,375g/plant hole (Table 5). The OPEFB addition that reached 6,750 g/plot would decrease the number of panicles per plant.

The low number of panicles per plant on the rice given high dose of OPEFB (K3) is assumed to have been caused by the uneven distribution of assimilates. The soils with a high water content as a result of the addition of high doses of organic matter will stimulate the number of tiller formations. Assimilates are more directed to the vegetative growth rather than generative one. Although the number of potential tillers contributes to the results of rice yields (Wu et al., 1998), the great number of tillers indicates inconsistency in the mobilization of assimilates and nutrients among tillers. As a result, there will be a variation of the distribution of assimilates between tillers and panicles formation (Miller et al., 1991).

\section{Number of filling grain:-}

The results of statistical analysis show that there is a significant interaction between OPEFB compost treatment and mycorrhizal inoculation to the number of filling grain per plant (Table 6). The highest average number of filling grain per plant is obtained in the treatment of interaction between K1 and M1 (OPEFB compost of 3,375g/planting hole and inoculated mycorrhizae), while the lowest average is obtained in the plants without being given compost and mycorrhiza. The results of this research indicate the ability of mycorrhizal inoculation to give $\mathrm{P}$ in the plants for energy fulfillment in seed formation.

The number of empty grain per plant:-

For the parameter number of empty grain per plant,there is a significant interaction between OPEFB compost treatment and mycorrhizal treatment. The highest number of filling grain parameter is obtained in K1M1, while the highest number of empty grain is obtained in K2M1.

The results of the research presented in Table 7 show that the increase in the addition of compost to the mycorrhizalinoculated soil will increase the amount of grain hollow. The increased number of empty grain in the increased 
doses of OPEFB compost and mycorrhizal inoculation is assumed to be caused by friable soil andsoil with sufficient water that will lead to an increased number of tillers. The increased number of these tillers will leadto the distribution of assimilatesto tillers growth resulting in a lack of assimilates in grain filling.

The research conducted by Wangiyana et al.(2009) shows that the great number of tillers results in the great number of empty grains because the grains are not filled through the process of photosynthesis and the high rate of photosynthetic partition during the grain filling phase. According to Soemartono et al. (1984), the number of productive tillers is determined by the number of tillers growing before reaching the primordial phase. However, there may be a chance that the tillers forming the last panicles may not produce a panicle with fully filled grains, so there is a chance of producing grain hollow. Feng et al.(2007) also found the different number of grains within the tillers. The results of their study concluded that the first tilleris more potential to produce seeds rather than the last tiller. This condition is assumed to be the factor causing an increase in the number of tillers, resulting in an increased number of empty grain.

\section{Production per plant:-}

From the results of the statistical analysis, it is found that the addition of OPEFB compost treatment gives significant effect to the crop production, while giving mycorrhiza and interaction between the two treatments does not.

OPEFB composting equivalent to $6,750 \mathrm{~g} / \mathrm{plot}$ produces the highest yield per plant. Such increased production per plant is assumed to be caused by fairly high potassium content in the planting media. Potassium is the macro nutrients that play a role in the metabolism of carbohydrates.

Although OPEFB compost treatment and mycorrhizal inoculation treatment statistically does not give significant effect, but there is an increase in the average weight of 1000 grains (Table 9).

The average weight of 1000 grains of Situ Bagendit variety treated by OPEFB compost and mycorrhizal is only about 11-14 g (Table 9). If this weight is compared to the value on the description (27-28 g), the result obtained will be half of its potential. This result indicates a decrease in grain weight of rice seeds during the dry season. Rainfall data at the research location obtained from RAMCG of Sampali, Medan, the planting was done in the dry season with rainfall of less than $100 \mathrm{~mm}$ (Figure 1).

Water deficit in rice planting response more seriously to generative phase rather than to vegetative phase (Kato et al., 2007). Therefore, upland rice cultivation should consider minimum water requirement to avoid a decrease in the yield (Matsumoto et al.,2014), whose amount depends on its varieties. Water plays an important role inrice cultivation; therefore, a sufficient amount of water supply is one of important factors in the production of rice. Rice crops will usually encounter stress if there is too little water (drought) or too much water (flooding). Limited availability of water causes discrepancy and variability of yield (Papademetriou, 2001).

Akinbile (2010) also found a significant difference between the observed variables in biomass and grain yield, LAI, plant height and maximum root depth among treatments with or without water supply. This result of research indicates that water is the main factor affecting grain yield.

\section{Conclusions:-}

The dose of OPEFB composting of 3,375 g per planting hole can increase the number of productive tillers and panicles. The addition of OPEFB (3,375 g/planting hole) and mycorrhizal inoculation ( $5 \mathrm{~g}$ mycofer/planting hole) can increase the number of filling grains of upland rice. The provision of mycorrhiza in the soil by adding organic matter causes the ineffectiveness of this microbial function.

\section{Acknowledgment:-}

Thanks to Ministry Research, Technology and Higher Education Directorate General Strengthening Research and Development that have funded this research. 


\section{References:-}

1. Abdurachman, A, Dariah A, and Mulyani A. (2008): Strategi dan teknologi pengelolaan lahan kering mendukung pengadaan pangan nasional. Jurnal Litbang Pert 27(2): 43-49.

2. Akinbile,C. O. (2010): Behavioural pattern of upland rice agronomic parameters to variable water supply in Nigeria. Journal of Plant Breeding and Crop Science Vol. 2(4), pp. 073-080.

3. Al-Karaki, G.N., and Clark, R. B. (1998): Growth, mineral acquisition, and water use by mycorrhizal wheat grown under water stress. J Plant Nutr 21:263-276

4. Al-Karaki, Ghazi, B. McMichael and John Zak. (2004): Field response of wheat to arbuscular mycorrhizal fungi and drought stress. Mycorrhiza 14:263-269

5. Allen, F. M. (2001): Modeling arbuscular mycorrhizal infection: is \% infection an appropriate variable?. Mycorrhiza10:255-258

6. Alloush,G. A., S. K. Zeto, andR. B. Clark. (2000): Phosphorus source, organic matter, and arbuscular mycorrhiza effects on growth and mineral acquisition of chickpea grown in acidic soil.Journal of Plant Nutrition, Volume 23, Issue 9, pp. 1351-1369.

7. Augé, R. M. (2001): Water relations, drought and vesicular-arbuscular mycorrhizal symbiosis.Mycorrhiza 11:342.

8. Auge, R. M., Schekel, K.A., and Wample, R. L. (1987b): Leaf water and carbohydrate status of VA mycorrhizal rose exposed to drought stress. Plant Soil 99:291-302.

9. Barea, J. M., Palenzuela, J., Cornejo, P., Sánchez-Castro, I., Navarro-Fernández, C., Lopéz-García, A., Estrada, B., Azcón, R., Ferrol, N., Azcón-Aguilar, C. (2011): Ecological and functional roles of mycorrhizas in semiarid ecosystems of Southeast Spain. Journal of Arid Environments 75:1292-1301

10. Biro Pusat Statistik. 2015: Provinsi Sumatera Utara dalam Angka 2014. Medan

11. Carrenho, R. Sandra F., Botelho Trufem, Vera Lúcia Ramos Bononi, and Eraldo Schunk Silva. (2007): The effect of different soil properties on arbuscular mycorrhizalcolonization of peanuts, sorghum and maize. Acta bot. bras. 21(3): 723-730.

12. Davies, F. T. Jr, Potter, J. R., and Linderman R. G. (1992): Mycorrhiza and repeated drought exposure affect drought resistance and extraradical hyphae development on pepper plants independent of plant size and nutrient content. J Plant Physiol 139:289-294.

13. Eastin, J.D. and C.Y. Sullivan (1984): "Environmental stress influences on plant persistence, physiology and production.". In Physiological Basis of Crop Growth and Development, M.B. Tesar (Ed.) American Society of Agronomy. Madison. Pp. 201-236.

14. European Environmental Agency (EEA) (2011): Global and European temperature (CSI 012/CLIM 001), Assessment May 2011. Copenhagen, http://www.eea.europa.eu/data-and-maps/indicators/global-and-european temperature/global-and-european-temperature-assessment-4Accessed on 20 Aug 2012

15. Feng Wang, Cheng Fang-min, Zhang Guo-ping. (2007): Difference in Grain Yield and Quality among Tillers in Rice Genotypes Differing in Tillering Capacity. Rice Science, 14(2): 135-140

16. Hanum, Ch., Delvian and Tuban Wibisono. (2006): Laporan Penelitian Hibah Bersaing. Lembaga Penelitian USU.

17. Hobbie, J. E. and Hobbie, E.A. (2006): $15 \mathrm{~N}$ in symbiotic fungi and plants estimates nitrogen and carbon flux rates in arctic tundra. Ecology, 87: 816-822

18. I Putu, W. and Sukawidana, I. M. (2011): Kondisi fisik, kimia dan biologi tanah pembibitan jambu mete akibat inokulasi mikoriza dan pupuk organik. Fakultas Pertanian Universitas Tabanan.

19. IPCC (2007) IPCC Climate change 2007: the physical science basis. In: Solomon S, Qin D, Manning M, Chen Z, Marquis M, Averyt K, Tignor MMB, Miller HL (eds) Working group 1 contribution to the fourth assessment report of the intergovernmental panel on climate change (IPCC). Chapters 3 (observations: surface and atmospheric climate change), 10 (global climate projections), 11 (regional climate projections). Cambridge University Press, Cambridge.

20. Joner, E. J and Jakobsen, I. (1995): Growth and extracellular phosphatase activity of arbuscular mycorrhizal hyphae as in ${ }^{-}$uenced by soil organic matter. Soil Biology and Biochemistry 27: 1153 \pm 1159 .

21. Kato, Y, Kamoshita, A., Yamagishi, J., and Abe, J. (2007): Growth of Rice (Oryza sativa L.) Cultivars under Upland Conditions with Different Levels of Water Supply 3. Root System Development, Soil Moisture Change and Plant Water Status. Plant Prod Sci 10: 3-13.

22. Matsumoto, S., Tsuboi, T., Asea, G., Maruyama, A., Kikuchi, M. (2014): Water Response of Upland Rice Varieties Adopted in Sub-Saharan. Africa: A Water Application Experiment. J Rice Res 2: 121. doi: $10.4172 / \mathrm{jrr} .1000121$. 
23. McCauley, Ann, Clain Jones, and Jeff Jacobsen.(2009): Soil pH and Organic Matter. Montana State University-Bozeman, Bozeman, MT 59717; (406) 994-5132; E-mail - publications@montana.edu.

24. Miller, B. C., Hill, J. E., and Roberts, S. R. (1991): Plant population effects on growth and yield in water-seeded rice. Agron J, 83: 291-297.

25. Papademetriou, M. K. (2001): Issues and perspectives of rice production in Asia and the pacific Region: In Yield Gap and productivity Decline in Rice production consultation held in Rome 5-7: 39-67.

26. Rahmalia,W., Yulistira, F., Ningrum, J., Qurbaniah, M.,and Ismadi, M. (2006): Pemanfaatan potensi tandan kosong kelapa sawit (Elais guineensis Jacq) sebagai bahan dasar c-aktif untuk adsorpsi logam perak.

27. Ruiz-Lozano, J. M. (2003): Arbuscular mycorrhizal symbiosis and alleviation of osmotic stress. Newperspectives for molecular studies. Mycorrhiza 13:309-317.

28. Ruiz-Sánchez, M., Aroca, R., Muñoz, Y., Armada, E., Polón, R., Ruiz-Lozano, J. M. (2010): The arbuscular mycorrhizal symbiosis enhances the photosynthetic efficiency and the antioxidative response of rice plants subjected to drought stress. J Plant Physiol 167:862-869.

29. Russell, E. W. (1973): Soil Conditions and Plant Growth. Longman London

30. Soemartono, Bahrin, Hardjono, and Iskandar.(1984): Bercocok Tanam Padi. CV. Yasaguna. Jakarta.

31. Tan, K.H. and A. Binger. (1986): Effect of humic acid on aluminium toxicity in corn plant. Soil.Sci., 14(1): 2025.

32. Wangiyana, W., Zapril, L., and Sanisah.(2009): Pertumbuhan Dan Hasil Tanaman Padi Var. Ciherang Dengan Teknik Budidaya "SRI (System Of RiceIntensification)" Pada Berbagai Umur Dan Jumlah Bibit Per Lubang Tanam. Faculty of Agriculture, Universitas Mataram, Mataram.

33. Wijaya, T.,Rosyid,M.J.,and Boerhendhy, I. (2001): Teknologi pengelolaan nutrisi dan air pada perkebunan karet. Pusat Penelitian Karet

34. Wu, G. W., Wilson, L. T., Mc Clung, A. M. (1998): Contribution of rice tillers to dry matter accumulation and yield. Agron J, 90: 317-323. 